up investigations in the geologic department of archæology without adequate knowledge either of the processes and phenomena of geology, or of the arts and habits of our aboriginal peoples." I had supposed that such crass ignorance as this was confined, in Mr. Holmes's judgment, to myself; but it seems that there are others falling under a like condemnation. How fortunate it is for the rising generation that $\mathrm{Mr}$. Wm. H. Holmes has appeared to set them quite right in regard to the prehistoric archæology of North America.

Boston, May 22.

\section{Preliminary Note on Eggs of Cottus Richardsoni.}

ONE finds in scientific literature so little relating to the habits of even some of our best-known fishes, that reliable information on piscine life-histories is much to be desired.

The little miller's thumb (Cottus Richardsoni, Agassiz) was found breeding plentifully in a large spring near Philadelphia on Apr. 29, and a fine lot of material for future embryological study procured.

The places selected for oviposition were invariably the fountain-heads of small, lateral springs which emptied into the main body of water, and where the water was freshest and coldest. No eggs were found at more than a few feet distance from a spring-head. In two or three cases the streams were so tiny that the fishes must have been forced almost to squirm along to the nesting-place. The greatest number, however, were found where a powerful current flowed from beneath an overhanging rock.

A passage is forced beneath a stone, which may be a mere pebble or a large boulder, and a small, shallow chamber hollowed out of the underlying soil, unless the stone be so supported that a natural chamber is formed beneath it. This accommodates the fishes during egg-laying and impregnation; and later serves the male as a resting-place. To the under side of the stone, which forms the roof of the chamber, the eggs are attached, not singly and in small clusters arranged in a single layer, as is the case with Batrachus and other fishes of similar habit, but in an irregular, coberent mass, in which the eggs are often piled up five or six deep, but in most cases are only two or three. The eggs, while very firmly coherent, are loosely arranged, giving the mass a very porous structure, which permits a free flow of fresh water. This is the more necessary since the eggs deeper in the mass are sometimes the first to hatch, when they frequently escape through the passages between the more superficial ones, the collapse of their own egg-membranes making additional room for those which follow. The number of eggs, and consequently the size and shape of the masses, varies, the eggs numbering from 120 to 500. In most cases all of the eggs in a mass were of approximately the same age; but several times, eggs in two or three stages of development were found together, the deepest, of course, being the most advanced. In the cases of most fishes, as is well known, the eggs all hatch, under favorable conditions, at the same time. Whether the several lots are deposited by different females, or whether the eggs are matured in several batches, and the female returns to complete ovipnsition, I cannot say.

The eggs when newly deposited are of a delicate, translucent, pink color. They average one-tenth of an inch in diameter, being large for the fishes' size, but are quite variable, and are often misshapen by contact with their fellows. As usual, the axis of the embryo passes through the lowermost pole, the dark, widely separated eyes being prominent objects on this side of the egg. There is no regularity about the direction of the embryonic axis, which, in the different eggs of a mass, is found to point in every direction.

Some of the eggs hatched while being conveyed home, and the young lived several days in an aquarium jar. They are very active little creatures, darting about in a most lively manner, often swimming to the surface and then sinking to the bottom, where they rest for a moment, before undertaking another excursion. This activity is exhibited from the time of hatching. When first hatched they are nearly a quarter of an inch long and far advanced in development. The pigmentation is very slight, there being no prominent aggregations of chromatophores anywhere except in the eses, which are densely pigmented. Branched pigment cells are scattered sparingly, especially on the dorsum of the head.

In every case the eggs were attended by the males, which showed no disposition to desert their posts, but remained motionless, trusting to their protective coloration for concealment.

Several of these males, which were thrown alive into a satchel, seemed to suffer no inconvenience whatever through their absence from water for three hours, but were at once active when placed in a dish.

J. Percy Moore.

\section{Gophers and Moles.}

IN the coursè of his interesting "Observations on Gophers and Moles" in your issue of April 28, Mr. F. L. Washburn makes mention of two moles which were fatally poisoned by eating worms taken from an old manure heap. I presume that the Oligocheta there identified as Lumbricus foetidus are equivalent or closely allied to those known to fishermen on this side of the water as " brandlings" (Allolobophora fotida), commonly found under manure and readily distinguished from the common earthworm (Lumbricus terrestris) by their display of brilliant red rings; and if this be so, I can add my testimony - founded on disastrous personal experience - that the unsavory annelid is toxic also to reptiles. This is somewhat remarkable, seeing that it is devoured with impunity by fish and amphibians. During a severe and prolonged frost, six or seven winters ago, when frogs and common earthworms were not to be obtained, I incautiously tendered a number of these brandlings to certain colubrine snakes, wild with hunger from enforced abstinence after casting their sloughs; they included several mocassins (Tropidonotus fasciatus), a Bordeaux snake (Coronella girondica), two garters (Tropidonotus ordinatus), two or three specimens of Lamenis atrovirens, and a whole brood of little Japanese vibakaris (Tropidonotus vibakari), born in my vivarium and the sole representatives of the species in Europe. The result was that within a very few minutes the whole lot, as well as a couple of South African slowworms and a large apadous lizard, the "glass snake" so-called (Pseudopus pallasi), were in violent convulsions; and although by prompt and vigorous measures I forced them to disgorge and got them all into hot baths as speedily as possible, I lost eight out of my forty-three vibakaris, the Bordeaux snake, both slow-worms, one dark green, and one garterhideous evidence of the baleful virulence of the foetidoe and the lamentable lack of instinctive discrimination on the part of the reptiles. Evidently the conspicuous coloration of this worm is not to be added to the list of protectives, since the creatures to which it is most exposed, frogs, toads, etc., prey on it with avidity. Serpents, as a rule, will not take worms unless they have been " taught" to do so - such tuition, however, being quite practicable.

Watford, Engiand. Arthur Stradling, C.M.Z.S., etc.

\section{BOOK-REVIEWS.}

Destructive Distillation. A Manualette of the Paraffin, Coal Tar, Rosin Oil, Petroleum, and Kindred Industries. By EDMUND J. Mills, D.Sc. (London), F.R.S. Fourth edition. London, Gurney \& Jackson. 200 p. $8^{\circ}$.

HISTORICALLY an ancient industry, this branch of scientific investigation has always proved most absorbing and as early as the sixteenth and seventeenth centuries upon it was concentrated the whole attention of the laboratory. Heat was considered in the medium of a reagent and in the retorts of the alchemists vegetable, animal, and mineral matter was subjected to "analysis." The above work by Dr. Mills, now in its fourth edition, with improvements including the results of much additional research, is founded upon a course of lectures delivered in Anderson College, Glasgow, and is illustrated by actual inspection of many of the processes referred to. Since the appearance of the first edition, in $\mathbf{1 8 8 7}$, the book has found its way into the hands of every technical student and every chemist the world over. Dr. Mills has become a recognized "authority" upon the subject, deserving and receiving the highest praise for his patient, earnest research. The main sections of the book are indicated by the title, 